\title{
Effect of inhibitor mixture composition on the protective properties in carbon-dioxide corrosion of steel
}

\author{
A. A. Markosyan, ${ }^{1}$ E. A. Kiyanitsa, ${ }^{1}$ V. V. Chernyavina, ${ }^{1}$ \\ A. G. Berezhnaya ${ }^{1}$ and V. I. Mishurov $^{2}$ \\ ${ }^{1}$ Southern Federal University, Zorge st., 7, Rostov-on-Don, 344090 Russian Federation \\ ${ }^{2}$ Don State Technical University, Gagarin sq., 1, Rostov-on-Don, 344010, \\ Russian Federation \\ E-mail: angela-markosyan@yandex.ru
}

\begin{abstract}
The problem of corrosion control is one of the cardinal problems in the gas-and-oil producing industry. Because of it, defects occur during operation of oil-field equipment that lead to financial expenses and environmental pollution. The use of inhibitors is the simplest and cheapest method of corrosion protection $[1,2]$. The presence of carbon dioxide in stratal water contributes to carbon dioxide corrosion of equipment. The specific features of this kind of corrosion require the selection of specific inhibitors in development and operation of wells. They must have high protective properties at minimal concentrations, have a positive impact on the processes of extraction, preparation, transportation and processing of oil and gas [3-8]. This paper presents the results on the effect of the composition and concentration of inhibitor mixtures on their protective properties in the corrosion of St3 steel in $\mathrm{CO}_{2}$ saturated solution of sodium chloride.
\end{abstract}

Key words: carbon dioxide corrosion, phosphorus surface active substances, chloride solutions saturated with $\mathrm{CO}_{2}$.

Received: December 10, 2014.

doi: $\underline{10.17675 / 2305-6894-2015-4-2-110-115}$

\section{Experimental}

Mixtures of isononylphenolethoxyphosphoric esters (phosphorus surface active substances, hereinafter referred to as P-SAS) and monoethanolamine (MEA) in a water-isopropanol solution were studied as corrosion inhibitors. The mass fraction of P-SAS in the formulation was $20 \%$ or $30 \%$ and the amine content was varied from 3.5 to $15 \%$. The corrosion behavior of St3 steel was studied in 3\% sodium chloride solution saturated with carbon dioxide ( $\mathrm{pH}$ 4.7). The technique of corrosion measurements and inhibitor efficiency evaluation was described previously [9]. The concentration range of the mixtures was 10$100 \mathrm{mg} / \mathrm{l}$.

Electrochemical measurements were carried out on a stationary electrode $(S=$ $0.5 \mathrm{~cm}^{2}$ ) on a PI-50-1 potentiostat in a three-electrode cell with separated cathodic and anodic spaces. A saturated silver chloride reference electrode and a platinum counter electrode were used. The potentials $(E)$ are given with respect to the standard hydrogen 
electrode. Before measurements, an electrode was activated for 5 minutes at $E=-0.80 \mathrm{~V}$, then polarization from the cathodic to the anodic region was carried out with exposure for 1 min at each $E$ value.

\section{Results and Discussion}

The corrosion rate of St3 steel in chloride solutions saturated with $\mathrm{CO}_{2}$ decreases with an increase in the concentration of all the mixtures studied, Table 1. The protective properties depend on the concentration of the mixture and on the MEA content in a mixture, Figure 1. The protection rating at the maximum concentration of $100 \mathrm{mg} / \mathrm{l}$ is $79-91 \%$, depending on the composition of the additive.

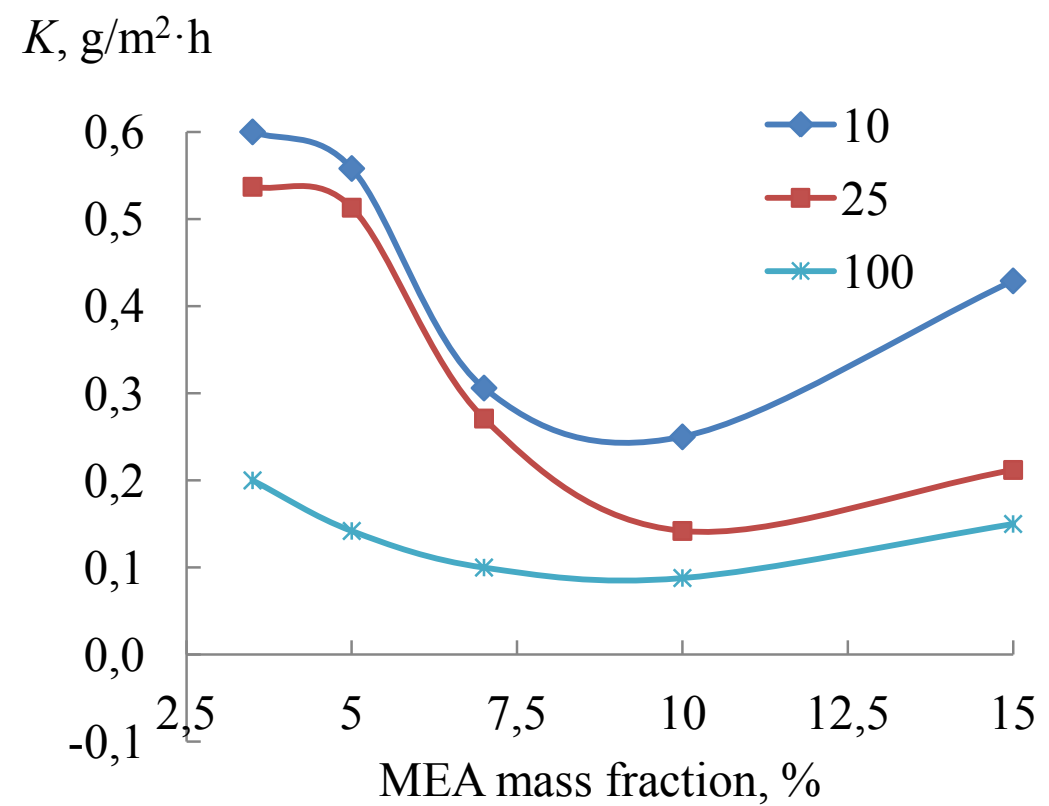

Figure 1. Dependence of the corrosion rate of St3 steel on the MEA mass fraction in the mixture in $3 \%$ sodium chloride solution saturated with $\mathrm{CO}_{2}$ at concentrations of 10,25 , and $100 \mathrm{mg} / \mathrm{l}$.

With an increase in IEA content in the mixture and at a constant concentration of PSAS, steel corrosion rate varies non-linearly at all the concentrations studied, Figure 1, Table 1. The best protective properties are observed for the mixture containing 10\% MEA. In this case, the corrosion rate is reduced to the maximum extent. A further increase in the MEA mass fraction to $15 \%$ leads to an increase in the corrosion rate and a decrease in the protective effect at all concentrations of additives, Figure 1.

The protective effect of the mixtures is evidently due to the formation of a surface adsorption complex by a lone-electron pair of the nitrogen atom of the inhibitor molecule and the d-orbital of an iron atom. According to [4], the inhibitor promotes the formation of a positively charged capacitor plate that prevents the transfer of $\mathrm{Fe}^{2+}$ through the oxide, 
Table 1. The inhibition ratio and the protection rating of inhibitor mixtures depending on the content of P-SAS and MEA at concentrations of $10,25,35,50$ and $100 \mathrm{mg} / 1$. The temperature was $20 \pm 20^{\circ} \mathrm{C}$, the duration of the experiments was 4 hours.

\begin{tabular}{|c|c|c|c|}
\hline Inhibitor mixture & $C, \mathrm{mg} / \mathrm{l}$ & $\gamma$ & $Z, \%$ \\
\hline \multirow{5}{*}{$\begin{array}{l}\text { P-SAS } 20 \% \\
\text { MEA } 3.5 \%\end{array}$} & 10 & 1.6 & 37 \\
\hline & 25 & 1.8 & 43 \\
\hline & 35 & 2.2 & 55 \\
\hline & 50 & 2.6 & 62 \\
\hline & 100 & 4.7 & 79 \\
\hline \multirow{5}{*}{$\begin{array}{c}\text { P-SAS } 20 \% \\
\text { MEA } 5 \%\end{array}$} & 10 & 1.7 & 41 \\
\hline & 25 & 1.8 & 46 \\
\hline & 35 & 2.8 & 64 \\
\hline & 50 & 6.0 & 83 \\
\hline & 100 & 6.7 & 85 \\
\hline \multirow{5}{*}{$\begin{array}{c}\text { P-SAS } 20 \% \\
\text { MEA 7\% }\end{array}$} & 10 & 3.1 & 68 \\
\hline & 25 & 3.5 & 71 \\
\hline & 35 & 8.4 & 88 \\
\hline & 50 & 8.4 & 88 \\
\hline & 100 & 9.5 & 89 \\
\hline \multirow{5}{*}{$\begin{array}{c}\text { P-SAS } 30 \% \\
\text { MAE 7\% }\end{array}$} & 10 & 4.1 & 76 \\
\hline & 25 & 4.9 & 80 \\
\hline & 35 & 5.4 & 81 \\
\hline & 50 & 5.8 & 83 \\
\hline & 100 & 7.6 & 87 \\
\hline \multirow{5}{*}{$\begin{array}{c}\text { P-SAS } 20 \% \\
\text { MEA } 10 \%\end{array}$} & 10 & 3.8 & 74 \\
\hline & 25 & 6.7 & 85 \\
\hline & 35 & 7.1 & 86 \\
\hline & 50 & 10.9 & 91 \\
\hline & 100 & 10.7 & 91 \\
\hline \multirow{5}{*}{$\begin{array}{c}\text { P-SAS } 20 \% \\
\text { MEA } 15 \%\end{array}$} & 10 & 2.2 & 55 \\
\hline & 25 & 4.5 & 78 \\
\hline & 35 & 4.6 & 78 \\
\hline & 50 & 5.0 & 80 \\
\hline & 100 & 6.3 & 84 \\
\hline
\end{tabular}


thus causing a decrease in the corrosion rate. The increase in corrosion rate with an increase in MEA content may be related to the hindered formation of a protective film of anodic products on the surface due to adsorption of MEA and phosphorus-containing anions of the inhibitor.

The change of P-SAS mass fraction in the mixture from $20 \%$ to $30 \%$ at a constant MEA content of $7 \%$ leads to an increase in the protective effect at low concentrations $(C \leq 25 \mathrm{mg} / \mathrm{l})$, Table 1. A further increase in the concentration does not lead to a significant increase in the protective effect. The protection rating with an increase in $C$ from $25 \mathrm{mg} / 1$ to $100 \mathrm{mg} / \mathrm{l}$ is $81-87 \%$.

Inhibition of both partial rates of the corrosion process and a change in the corrosion potential $\left(E_{\text {cor }}\right)$ are observed upon addition of the mixture to a $\mathrm{CO}_{2}$ saturated $3 \%$ sodium chloride solution, Figures 2, 3.

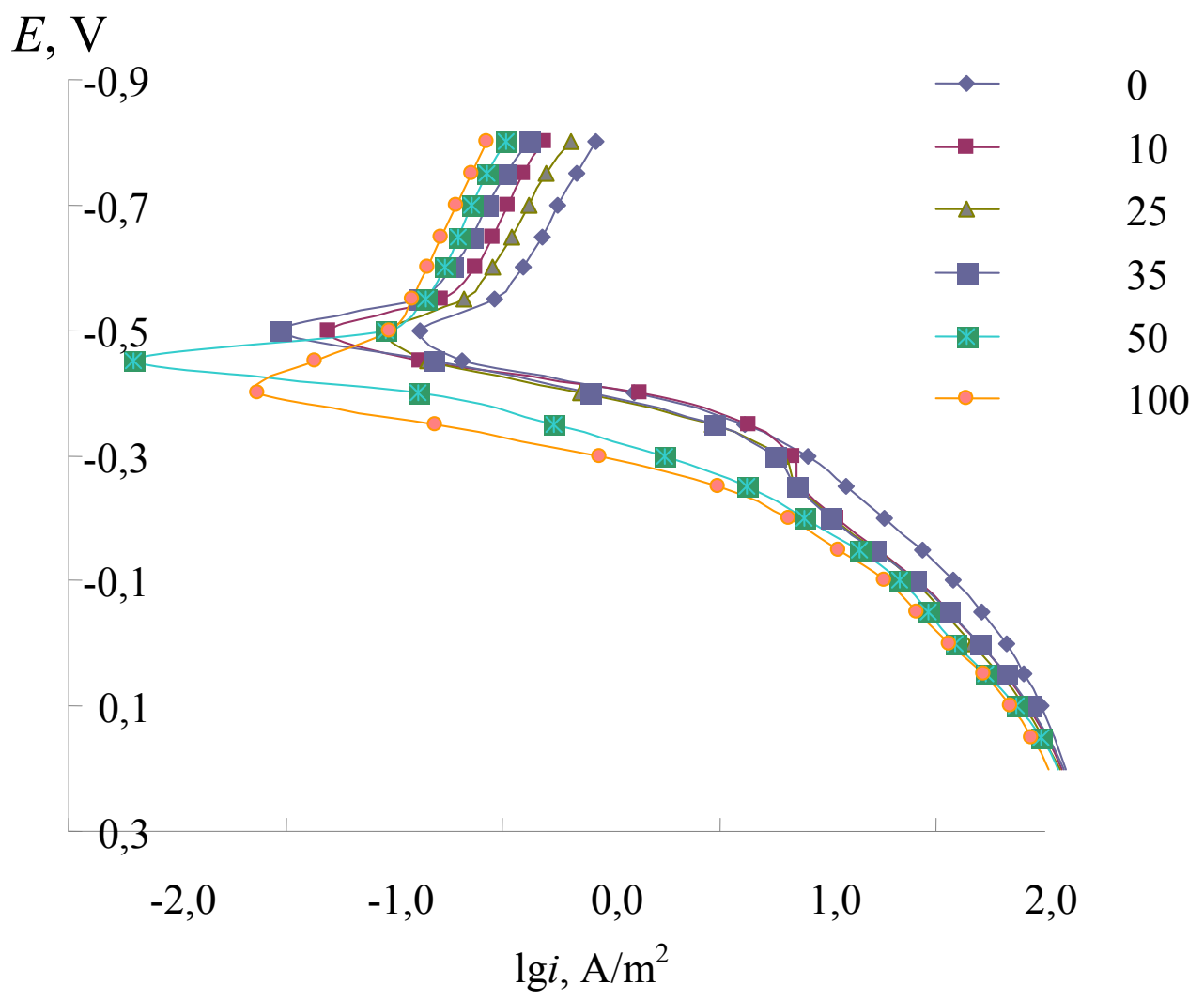

Figure 2. Polarization curves of St3 in $\mathrm{CO}_{2}$-saturated chloride solution without (0) and in the presence of a mixture of $20 \%$ P-SAS and $7 \%$ MEA at concentrations of $10,25,35,50$, and $100 \mathrm{mg} / \mathrm{l}$.

The corrosion potential increases with the concentration of the mixture, indicating preferential inhibition of the anodic reaction rate. The mixture containing $20 \%$ P-SAS and $7 \%$ MEA with concentrations of $C<50 \mathrm{mg} / \mathrm{l}$ is characterized by a slight protective effect, Table 2. 


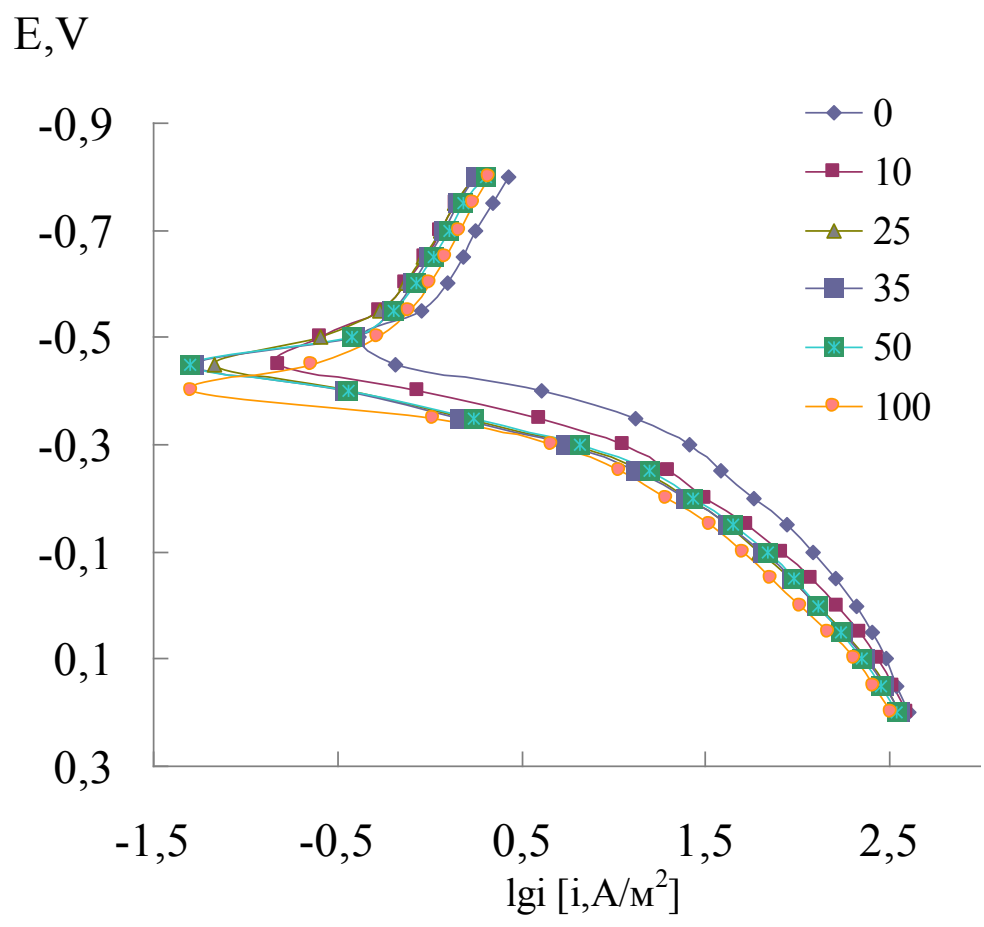

Figure 3. Polarization curves of St3 in $\mathrm{CO}_{2}$-saturated chloride solution without (0) and in the presence of a mixture of $30 \%$ P-SAS and 7\% MEA at concentrations of 10, 25, 35, 50, and $100 \mathrm{mg} / \mathrm{l}$.

Table 2. The dependence of $\gamma$ and $Z$ on the potential and concentration of the mixture based on an analysis of polarization curves.

\begin{tabular}{|c|c|c|c|c|c|c|c|c|c|c|c|}
\hline \multirow{3}{*}{ Inhibitor mixture } & \multirow{3}{*}{$\begin{array}{c}C, \mathbf{m g} / \mathbf{l} \\
10\end{array}$} & \multicolumn{10}{|c|}{$\gamma$ and $Z$ values in $\%$ at $E, V$} \\
\hline & & \multicolumn{2}{|c|}{-0.6} & \multicolumn{2}{|c|}{-0.4} & \multicolumn{2}{|c|}{-0.3} & \multicolumn{2}{|c|}{-0.2} & \multicolumn{2}{|c|}{-0.1} \\
\hline & & 1.7 & 41 & 0.9 & - & 1.2 & 15 & 1.7 & 40 & 1.5 & 32 \\
\hline \multirow{4}{*}{$\begin{array}{c}\text { P-SAS } 20 \% \\
\text { MEA } 7 \%\end{array}$} & 25 & 1.4 & 29 & 1.8 & 44 & 1.3 & 26 & 1.7 & 41 & 1.5 & 35 \\
\hline & 35 & 2.1 & 53 & 1.6 & 38 & 1.4 & 31 & 1.8 & 44 & 1.5 & 34 \\
\hline & 50 & 2.3 & 57 & 10.0 & 90 & 4.7 & 79 & 2.3 & 57 & 1.8 & 44 \\
\hline & 100 & 2.8 & 64 & 55.0 & 98 & 9.1 & 89 & 2.8 & 64 & 2.1 & 52 \\
\hline \multirow{5}{*}{$\begin{array}{c}\text { P-SAS } 30 \% \\
\text { MEA } 7 \%\end{array}$} & 10 & 1.7 & 41 & 4.7 & 79 & 2.3 & 56 & 1.8 & 45 & 1.5 & 32 \\
\hline & 25 & 3.8 & 74 & 11.0 & 91 & 4.3 & 77 & 2.3 & 56 & 1.9 & 49 \\
\hline & 35 & 1.5 & 35 & 11.7 & 91 & 4.7 & 79 & 2.3 & 57 & 1.9 & 46 \\
\hline & 50 & 1.5 & 32 & 11.2 & 91 & 3.9 & 74 & 2.1 & 53 & 1.7 & 42 \\
\hline & 100 & 1.3 & 21 & 79.4 & 99 & 5.5 & 82 & 3.0 & 66 & 2.3 & 57 \\
\hline
\end{tabular}

As concentrations $C \geq 50 \mathrm{mg} / 1$ the protection rating at $E=-0.4 \mathrm{~V}$ close to $E_{\text {cor }}$ is $90-$ $98 \%$. These values agree with the results of gravimetric measurements. With an increase in 
potential the protection rating decreases and at $E=0.0 \mathrm{~V}$ it is $41-45 \%$. A change in PSAS content in the mixture to $30 \%$ leads to an increase in the protection rating at low concentrations and $E$ close to $E_{\text {cor }}$, Figure 3, Table 2 . In the vicinity of $E_{\text {cor }}$ at $C=10 \mathrm{mg} / \mathrm{l}$, the protection rate is $79 \%$. There is a decrease in the protection rate at all concentrations with an increase in potential. At $E \geq-0.4 \mathrm{~V}$ the protection effect is nearly independent of the composition of the additive, Figure 3.

\section{Conclusion}

1. The investigated mixtures exhibit protective properties in $\mathrm{CO}_{2}$ saturated aqueous chloride media. The protection rating of mixtures at a concentration of $\geq 50 \mathrm{mg} / \mathrm{l}$ is $80-90 \%$.

2. The corrosion rate of steel depends on the content of MEA in the mixtures and is not linear at all investigated concentrations. The mixture containing 10\% MEA exhibits the best protective properties.

3. Increasing the P-SAS content in the mixture leads to an increase in the protective effect at low concentrations.

4. The investigated mixtures are anodic-cathodic inhibitors. The protective effect decreases with an increase in the potential.

\section{References}

1. I. L. Rozenfel'd, Ingibitory korrozii (Corrosion inhibitors), Moscow, Khimiya, 1977 (in Russian).

2. Yu. I. Kuznetsov, Int. J. Corros. Scale Inhib., 2012, 1, no. 1, 3. doi: 10.17675/23056894-2012-1-1-003-015

3. F. M. Mustafin, L. I. Bykov and A. G. Gumerov, Promyslovye truboprovody $i$ oborudovanie (Field pipelines and equipment), Moscow, Nedra (in Russian).

4. V. I. Vigdorovich, L. E. Tsygankova, N. V. Loktionov and N. V. Shel, Int. J. Corros. Scale Inhib., 2013, 2, no. 2, 115. doi: 10.17675/2305-6894-2013-2-2-115-121

5. I. S. Sivokon, Yu. B. Makarychev, Y. A. Kuzenkov and N. N. Andreev, Int. J. Corros. Scale Inhib., 2013, 2, no. 3, 203. doi: 10.17675/2305-6894-2013-2-3-203-215

6. I. S. Sivokon, D. B. Vershok and N. N. Andreev, Int. J. Corros. Scale Inhib., 2012, 1, no. 2, 130. doi: $10.17675 / 2305-6894-2012-1-2-130-145$

7. V. I. Vigdorovich, L. E. Tsygankova and N. V. Shel, Int. J. Corros. Scale Inhib., 2012, 1, no. 1, 38. doi: $10.17675 / 2305-6894-2012-1-1-038-050$

8. L. E. Tsygankova, M. N. Esina, V. I. Vigdorovich and N. V.Shel, Int. J. Corros. Scale Inhib., 2014, 3, 1, 48. doi: 10.17675/2305-6894-2014-3-1-048-058

9. V. V. Chernyavina and O. A. Ivashchenko, Vestnik Tambovskogo universiteta. Seriya: Estestvennye i tekhnicheskie nauki, 2013, 18, no. 5, 2341 (in Russian).

10. S. E. Sinutina, L. E. Tsygankova, Vestnik Tambovskogo universiteta. Seriya: Estestvennye i tekhnicheskie nauki, 1997, 2, no. 3, 310 (in Russian). 